\title{
Correction: Extracellular vesicles package dsDNA to aggravate Crohn's disease by activating the STING pathway
}

Fan Zhao, Tao Zheng, Wenbin Gong, Jie Wu (D), Haohao Xie, Weijie Li, Rui Zhang, Peizhao Liu, Juanhan Liu, Xiuwen Wu, Yun Zhao and Jianan Ren iD

(c) The Author(s) 2021

Cell Death and Disease (2021)12:1022; https://doi.org/10.1038/s41419-021-04340-0

Correction to: Cell Death and Disease https://doi.org/10.1038/ s41419-021-04101-z, published online 27 August 2021

The original version of this article unfortunately contained a mistake. An image of the STING KO mice (without DSS) was mistakenly used for the representative colon H\&E images for wild type mice (without DSS) during the compilation of Fig. 5E. The authors apologize for the error. The correct Fig. 5E can be found below.

\begin{abstract}
(c) (i) Open Access This article is licensed under a Creative Commons Attribution 4.0 International License, which permits use, sharing, adaptation, distribution and reproduction in any medium or format, as long as you give appropriate credit to the original author(s) and the source, provide a link to the Creative Commons license, and indicate if changes were made. The images or other third party material in this article are included in the article's Creative Commons license, unless indicated otherwise in a credit line to the material. If material is not included in the article's Creative Commons license and your intended use is not permitted by statutory regulation or exceeds the permitted use, you will need to obtain permission directly from the copyright holder. To view a copy of this license, visit http://creativecommons. org/licenses/by/4.0/.
\end{abstract}

(c) The Author(s) 2021 

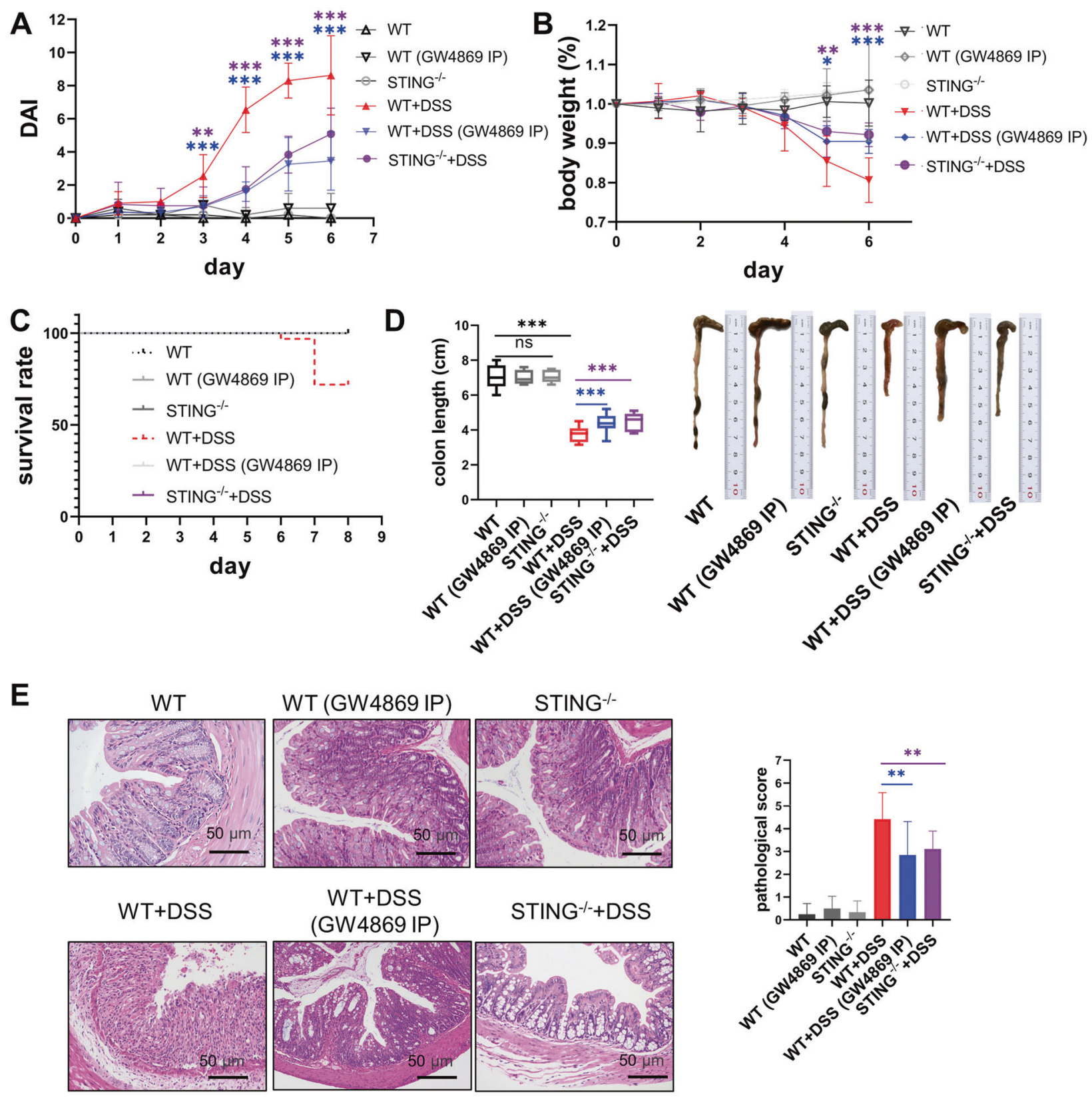